\title{
The Application of Solar Energy in Agricultural Systems
}

\author{
Mohammad Vahedi Torshizi and Atefeh Hosseini Mighani \\ Department of Bio-System Mechanical Engineering, Gorgan University of Agricultural Sciences and Natural \\ Resources, Gorgan, Iran. \\ mohammadvahedi4130@gmail.com
}

\begin{abstract}
Given that one day fossil fuels will end, a need arises to find alternative fuels. Renewable energy is considered an alternative to fossil fuels and nowadays it attracts much attention. Among renewable energy sources, solar is the most important because it is available in all parts of the world. Also, this energy source is used in various industries including agriculture and it can be used in cultivating crops in the farthest corners of the world. In addition, this fuel does not cause pollution, like the other fossil fuels.
\end{abstract}

Using the solar energy can be active in all agricultural areas. That will definitely help meet the increasing need for agricultural products with the increasing population. However, it is known that the agricultural land has a fixed area and, sometimes, agricultural products cannot be cultivated. That greenhouse is a method that is used nowadays and using the solar energy can help build solar greenhouses in areas far away from the city. Other applications of solar energy include irrigation, drying products, and ventilation niches. In this study, the researchers discuss some of the benefits of solar energy in agriculture.

Keywords - Fossil fuels, Solar Energy, Agriculture.

\section{INTRODUCTION}

The energy sector has a direct impact on the economic development of a country [1]. Nowadays, $85-90 \%$ of the world's primary energy is produced from fossil fuels [2]. There is a limited storage of fossil fuels and one of the important reasons for recession in world's economy is the continuously increasing prices of these fuels [3]. To solve the problem of the decreasing economy and the energy sector's related issues, all the world is focusing on an effective utilization of renewable energy resources like solar, wind, thermal and hydro [4,5]. Fossil energy supplies became available about 200 years ago [6]. In addition, shortages of cropland, fresh water, fossil energy (fertilizers and irrigation), and biological resources now plague agricultural production in many parts of the world [7]. However, resources of fossil energy have begun to decline and this trend intensified after the year 2000 [8]. The Use of renewable energy in the farming systems have several different applications. Applications of renewable energy also include generation of power to do a number of farm works: pumping water for irrigation, for keeping livestock, or for domestic use; lighting farm buildings; powering processing operations, and other uses. These forms of renewable energy include solar energy, wind and water power, oil from plants, wood from sustainable sources, other forms of biomass (plant material), and biogas (gas produced from fermentation of manure and crop residues) [9]. The foundation of all agricultural production rests on the unique capability of plants to convert solar energy into stored chemical energy [8]. Solar energy is the most appropriate option among other renewable energy sources because the solar energy level is in line with the air condition demand [10]. Also, solar energy technologies have a long history. Between 1860 and the First World War, a range of technologies developed to generate steam by capturing the sun's heat to run engines and irrigation pumps [11]. Taking into consideration the importance of solar energy and the increased attention humans are paying to renewable energy, this paper investigates the solar energy system in farming.

\section{SOLAR ENERGY TECHNOLOGIES}

There are two ways to convert solar energy into electrical energy; a system using photovoltaic technology and another that uses solar capture heating systems [12]. In the photovoltaic system, the sun rays are converted directly to electricity by semiconductors. In addition, in the method of heating, electrical power via the thermodynamic processes, with help of heat exchange equipment, can be converted to mechanical energy. These two methods are centralized and non-centralized. The photovoltaic method leads to more investments. However, in recent years with advances in the field of solar energy, thermal methods are used for power supply. 


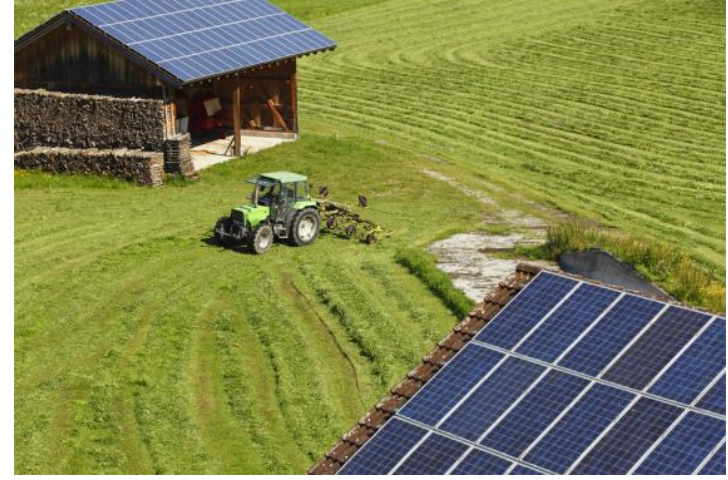

Fig .1. Use of solar energy in agriculture

\section{PHOTOVOLTAIC TECHNOLOGY}

Solar photovoltaic (PV) cells were invented at Bell Labs in the United States in 1954, and they have been used in space satellites for electricity generation since the late 1950s [12]. In this technology, solar rays collected via small plates that are semiconductor photovoltaic, are converted into electricity. Photovoltaic cells can be built in two ways: concentrator and flat panel. Solar cells are the most common type of flat panels where the light is immediately brought to semiconductor and is converted to electricity. Yet, in the concentrator cells, first the sunlight is guided via the reflector, concentrated, and then the solar cell connects together. The solar cells are formed by solar modules. Power cells and solar modules may be enough only to charge the battery and to build a system with output significantly requires that modules (Figure.3) that work together and at same time. Given that solar cells are connected together and making modules, also the modules for creating the appropriate voltage and current, are connected in series and parallel to that unit made in this way is called the Solar Array [13].

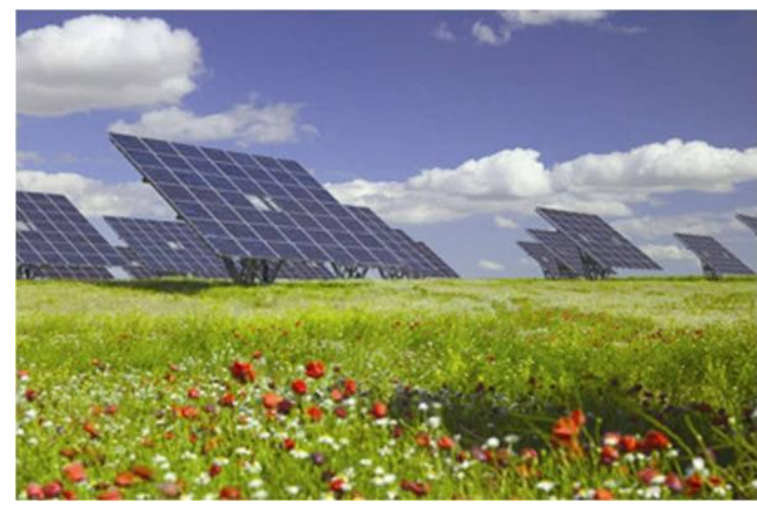

Fig.2. Solar photovoltaic panels providing green energy for agricultural growth

\section{SOLAR DRYER}

Preservation of food through drying is one of the oldest and the most widespread methods that can be used to enhance the strength of the food. Drying food is removing the moisture so that the product can be stored for a long time and be protected against corruption [14]. By reducing the microbial enzyme activity and reducing the speed of chemical reactions, drying increases shelf life of the product. In addition, reducing the weight and volume of materials and packaging, facilitates transportation and storage of products and decreases the cost of these procedures [15]. In the case of drying, in addition to preventing the loss, the marketing can be controlled at sensitive times and potatoes required by many consumers (such as barracks, restaurants, etc.) can be delivered in a dried form [16]. Using the sun for dry crops and grain is one of the oldest used applications of solar energy. Solar dryers protect grain and fruits and vegetables, reduce losses, dry faster and more uniformly, and produce a better quality product than open-air methods [17]. Solar-drying technology offers an alternative, which can process the vegetables and fruits in sanitary conditions to national and international standards and with zero energy costs. It saves energy, time, occupies less area, improves product quality, makes the process more efficient and protects the environment. [18] Much research has been conducted about the dryer that Kiebling has listed 66 different solar dryers, their (continue from the coming line) configurations, capacity, the products dried and their cost. [19] Fuller (Fuller, 1995) [20] and Ekechukwu et al. [21] have reviewed many solar dryers, and compared their performance and applicability in rural areas. Sharma [18] has presented a comprehensive review of the various designs, details of construction and operational principles of the wide variety of practically realized designs of solar-energy drying systems and a systematic approach for the classification of solarenergy dryers has been evolved. A review of new technologies, models and experimental investigations of solar driers has been presented by Ramana [22]. 


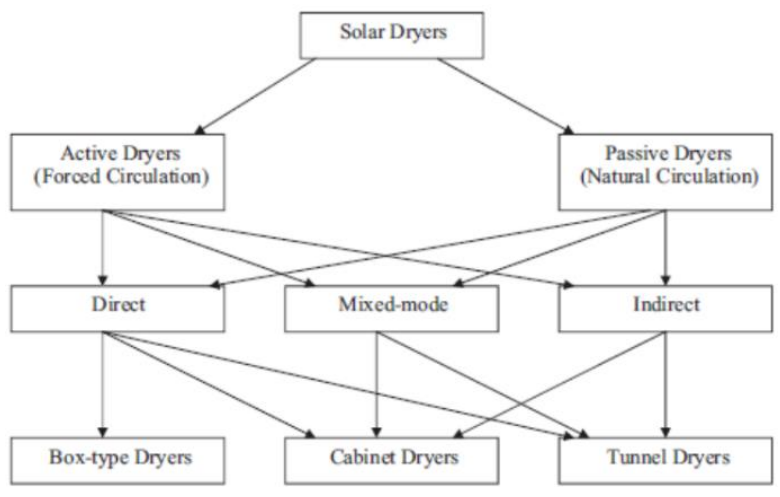

Fig.3. Classification of solar dryers and drying modes

Solar dryers are conventional dryers so that supplementary equipment is added to enable a significant proportion of the thermal energy required for drying to be replaced by solar energy. In these types of dryer, a planned, and generally optimized drying process can be achieved to obtain superior product quality and good economic performance. Any influence of the weather conditions on product quality and on the performance of the dryer can be eliminated by using an independent energy source, if needed, and proper control facilities [23]. The construction of the solar assisted dryers is relatively complex compared to other dryers. They usually consist of a solar collector, a fan, a heat storage system, a burner/heater, and a control system. They can handle large quantities and deliver good product quality [24].

\section{VENTILATION SYSTEMS FOR AGRICULTURAL APPLICATIONS}

Therefore, the application of PV can be the best choice because in the event of a grid power break down, PV will take over to supply power, hence potentially saving thousands of birds. Direct current motors can also operate directly with PV power and eliminate the use of an expensive inverter. The Taiwanese government increases benefits for livestock farmers who use solar energy to generate electricity specifically for pig farms to attract other farmers to build solar farms. A final report on Delaware's poultry farms reveals the economic and technical aspects of PV application for poultry farming. It also reports that PV offers additional benefits, such as security of supply, and economic and environmental advantages over grid electricity supply and conventional energy sources [25, 26].

\section{USE OF SOLAR ENERGY IN FARM HOUSES}

Electrification to farm is difficult in some places and the cost is very high and for the sake of reducing costs, solar energy can be used because it is available in all locations and can provide the electricity and fuel needed, for a home can provide home lighting lamps and other appliances, with using solar energy. But the question is for cooking and heating water heaters: What should one do? It is true to fix such problems by using solar cookers and water heaters.

\section{SOLAR HOME}

Seamlessly photovoltaic building that has been worn and has become one of the most popular homes. And it is used more in areas where there is not electrical grid. Photovoltaic panels are installed on the roof or walls to get sunlight. Solar energy is produced in the same location and can also save additional energy. This technology is cheaper and promising and more power can be produced for home. Figure below is a model configure to indicate buildings with photovoltaic energy. For areas where electricity grids are not very useful, it helps the region supply with the fewest problems of electricity [27]

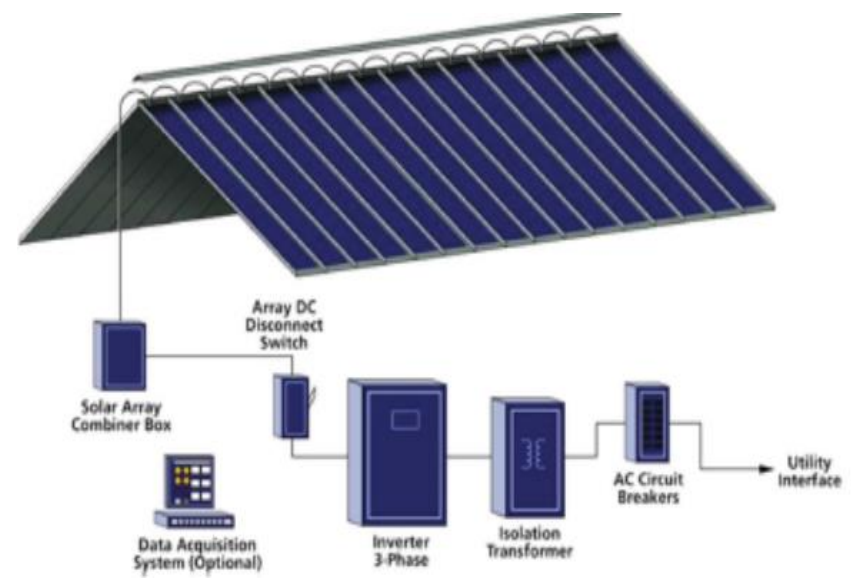

Fig.4. Building integrated photovoltaic system

\section{SOLAR COOKER}

Solar cookers are systems of clean energy, available and inexpensive sun that is used for cooking food. A solar cooker inhabited radiant heat by rays focusing it on a surface or locking it in a greenhouse space. Rather it should be used for cooking [28]. Given that in developed countries about $90 \%$ of household 
energy consumption is devoted to cooking [29]. These systems can do almost everything like an electric rice cooker or gas stove, such as roasting, brewing, cooking, frying or reheating refrigerated cool foods, including cases that are possible with the solar cookers [30], hence solar cookers are in two forms, direct and indirect. The direct solar cooker consists of an insulated box with transparent window, through which the sunlight enters. It is the most developed and it is for home cooking [27]. In the indirect stove fluid is used for heat transfer from the collector to a baking sheet [31].
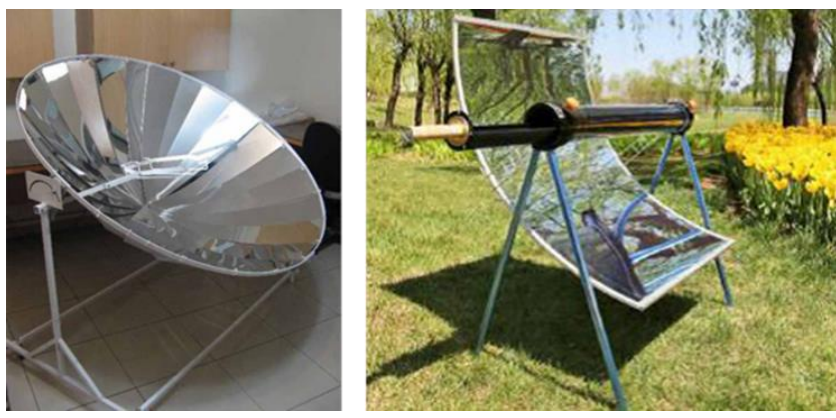

Fig.5. Schematic solar cooker

\section{SOLAR WATER HEATER SYSTEMS}

Water heaters are one of the most common applications of solar energy for home and industrial applications and similar solar dryers, water heating systems are also available in natural convection and forced convection scheme and Figure (6) shows one water heater [9]. Solar water heaters are divided into two categories: direct and indirect. In direct water heaters, water is consumed in the current collector, becomes hot and then is consumed, but in the indirect water heater, the water consumed is used for heating a fluid. The disadvantage of direct solar water heaters is that after a while the collector is blocked with a crime. Also, the thermal energy transfer to the water consumed is wasted [32].
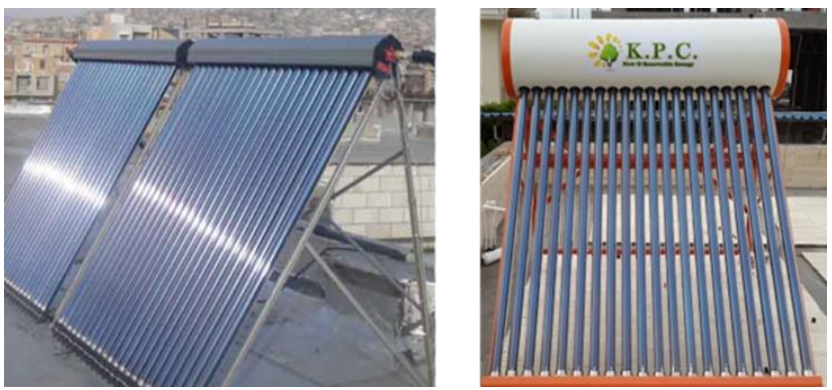

Fig.6. A sample of a solar water heater
In general, in solar water heaters, in order to use hot water when not benefitting from the sun, the hot water is stored in the reservoir. In some solar water heaters, a water tank is installed above the collector and hot water for natural convection is stored in the tank. To the water heater said thermo syphon. In Figure (7) shows a direct solar water heater [33].

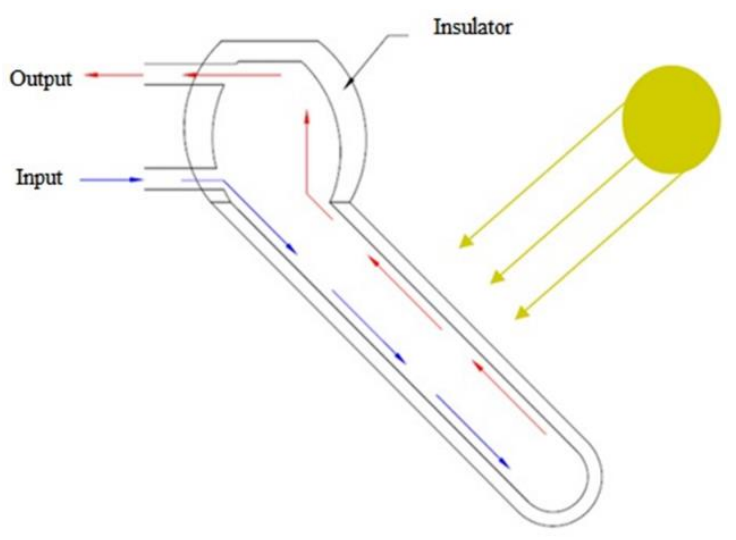

Fig.7.Schematic direct solar water heaters

In the indirect solar water heaters, a tank is installed in a separate space in order to provide power to flow in the collector by the used pump. That is why this water heater is said to be under pressure. In Figure (8) a indirect solar water heater is shown [33].

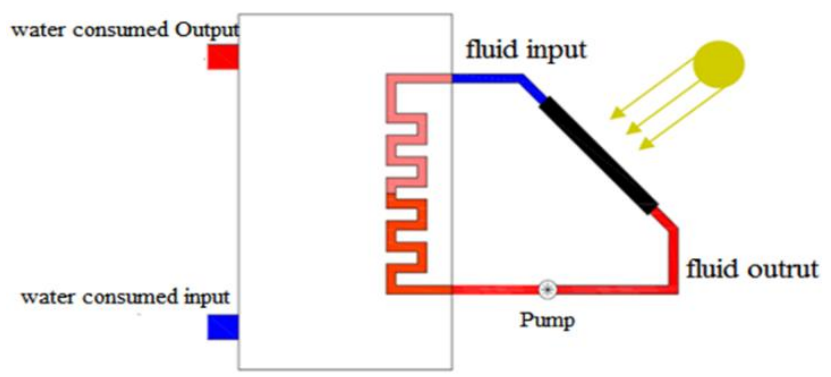

Fig.8. Schematic indirect solar water heaters

\section{SOLAR GREENHOUSE}

The greenhouse is a structure that nowadays is used in agriculture to grow plants with the best quality. Recently, solar energy is used for heating greenhouses so that such greenhouses are known as solar greenhouses (Figure 9) and the solar energy can be used to provide light to the greenhouse. A very good step would be to reduce the need for fossil fuels used for heating [34]. After the oil crisis in 1973, researchers tried find to a convenient and simple solution for the use of solar energy in the greenhouse. Overall, solar energy is used in greenhouses in three forms. The first type is famous 
as the inactive greenhouse (Passive), and it uses thermal energy from radiation solar heated greenhouse. In the greenhouse, the construction method is carried out so as to provide the maximum use of solar radiation during the day and lead to the lowest energy losses during the night in greenhouses. The second type greenhouse is called greenhouse active (Active), and it uses the pickers and transfer heated fluid, in heating greenhouses. In the third kind of greenhouses photovoltaic cells are used so that the solar radiation energy becomes Electrical and then it is used in greenhouses [35, 36].

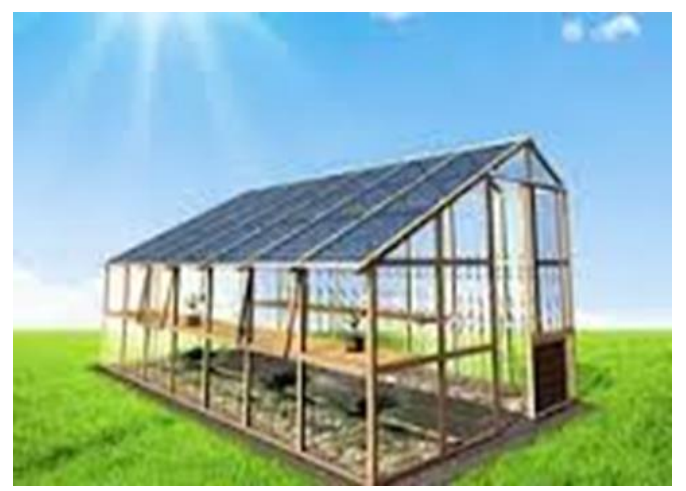

Fig.9. A sample of a solar greenhouse

\section{CONCLUSION}

The solar energy can be found in the farthest corners of the world and it can be developed to electric power production and agriculture. one reason that, agriculture is not anywhere, and is lack of energy. But Using solar energy can do the majority of cases related to agriculture. In addition, due to the reduced fossil fuel energy and Also with using solar energy in agriculture can land, that is unusable into them, created the greenhouse or place for breeding animals converted in areas outside city. On foregoing, the use of solar energy is an investment for the future because we can use it for a long time. In addition, a company can use this method to create, build panels and install them. This creates jobs and helps the economy.

\section{REFERENCES}

[1] Aqeel and M.S. Butt. "The relationship between energy consumption and economic growth in Pakistan." Asia-Pacific Dev J, vol. 8, pp. 101109, 2001.

[2] Christ of Ruehl GCE, 60 Years BP Statistical
Review, BP Energy Outlook-2030. London, 2011.

[3] S. Ali. "Total factor productivity growth in Pakistan's agriculture: 1960-1996." Pakistan Institute of Development Economics, Islamabad .vol. 43, pp. 493-513, 2005.

[4] A. Mehmood, A. Wasy, A. Waqas and J.Il. Song. "Development and computational flow analysis of GSM based automated solar water pump." 9th International Conference $\neg$ on $\neg$ Fracture \& $\neg$ Strength $\neg$ of Solid, pp. 1-8ᄀ, 2013.

[5] Mehmood, A. Waqas and H.T. Mahmood. "Economic viability of solar photovoltaic water pump for sustainable agriculture growth in Pakistan." Materials Today Proceedings $\urcorner$ vol. 2ᄀ, pp. -5190-ר195, 2015.

[6] WHO. "Micronutrient Malnutrition -- Half of the World's Population Affected." World Health Organization, no. 78, pp. 1-4, 13 Nov., 1996.

[7] D. Pimentel, X. Huang, A. Cardova and $M$. Pimentel. "Impact of a growing population on natural resources: the challenge for environmental management," In L. Hens and D. Devuyst, eds. Environmental Management in Practice: Analysis, Implementation, and Policy. Brussels, Belgium: 1998, pp1-12.

[8] D. Pimentel, M. Pimentel and M. KarpensteinMachan. "Energy use in agriculture: an overview."ᄀ Cigr, vol. ᄀา1, pp1-32.

[9] S.M. Ali, N. Dash and A. Pradhan. "Role of renewable energy on agriculture." International Journal of Engineering Sciences \& Emerging Technologies, vol. 4, Issue 1, pp. 51-57, Dec. 2012.

[10] K. Bataineh and Y. Taamneh, "Review and recent improvements of solar sorption cooling systems," Energy Build, vol. 128, pp. 22-37, 2016.

[11] Smith. "Revisiting solar power's past. Technology Review.” pp. 38-47, July, 1995.

[12] M. Hoogwijk. "On the global and regional potential of renewable energy sources." Faculteit Scheikunde, Universiteit Utrecht: 2004. 
[13] M.H. Shams, F. Khavari, M. Mohammadi and J. Noori. "A review of the technologies electric power generation statistical comparison of the sun and the largest world solar power plants." Journal of Industrial Technology Development, vol. 21 pp1-22, 2012. (in Persian)

[14] M. Zhang, C.L. Li and X.L. Ding. "Effects of heating conditions on the thermal denaturation of white mushroom suitable for dehydration." Drying Technology, vol. 23, no. 5, pp. $\neg 1119$ 1125, 2005.

[15] M.D. Ranken and R.C. Keel. "Solar-powered irrigation: A solution to water management in agriculture vol. 2, pp. $\neg 279-300,1999$.

[16] S.H. Najafi and M. Ghodsevarhani. "Collection of articles of food science and technology." Mashhad, pp. $\neg 115-121,1998$.

[17] L.M Diamante and P.A Munro. "Mathematical modeling of the thin layer solar drying of sweet potato slices." Solar Energy, 51, pp. 271-6, 1993.

[18] A. Sharma and C. Chen. "Nguyen VL. Solarenergy drying systems a review." Renewable and Sustainable Energy Reviews, vol. 13, pp. 1185-210, 2009.

[19] J. Kiebling. "Solare Trochner-Eine Tabellarische Ubersicht" (in German), "Deutsche Gesellschaft fur Technische Zusammenarbeit (GTZ) GmbH, OE 402.2.Information and Advisory Service for Appropriate Technology (ISAT)." ProjektNummer: 88.3-03-100, 2000.

[20] R.J. Fuller. "A review of solar drying of fruit, vegetables and other food crops." Australia: Agriculture Victoria (A division of the Dept. of Natural Resources and Environment), 1995.

[21] O.V. Ekechukwu and B. Norton. "Review of solar-energy drying systems. II: an overview of solar drying technology." Energy Conversion and Management, vol. 40, pp. 615-55, 1999.

[22] M.V. Ramana. "A review of new technologies, models and experimental investigations of solar driers." Renewable and Sustainable Energy Reviews, vol. 13, pp. 835-44, 2009.
[23] G.J. Christopher. "Industrial drying of foods." 309 p., 1997.

[24] Y .Hui. "Food drying science and technology." DEStech Publications, 2007.

[25] D.Bikash. "Solar powered lighting and ventilation of poultry house." MS thesis. Mymensingh: Bangladesh Agricultural University, Department of Farm Power and Machinery, 2014.

[26] M. I. Hussain. "Utilization of solar energy in agricultural machinery engineering." Journal of Biosystems Engineering, vol. 40, no. 3, pp. 186192, 2015.

[27] S.Roblin. "Solar-powered irrigation: A solution to water management in

agriculture." Renewable Energy Focus, Vol.17, pp205-206, 2016.

[28] K. Schwarzera. and D. Vieira and M. E. Silva. "Solar cooking system with or without heat storage for families and institutions." Solar Energy, vol. 75, pp. 35-41, 2003.

[29] N.M. Nahar and P. Gupta. "Energy conservation potential for solar cookers in arid zones of India." Energy, vol. 16, pp. 965-969 1991.

[30] M. S. Al-Soud, , E. Abdallah, A. Akayleh, S. Abdallah and E. S. Hrayshat. "A parabolic solar cooker with automatic two axes sun tracking system." Applied Energy, vol. 87, pp. 463-470, 2010.

[31] A. Saxena, R.Varun, S.P. Pandey, G. Srivastava."A thermodynamic review on solar box type cookers. "Renewable and Sustainable Energy Reviews, Vol. 15, no 6, pp. 3301-3318, 2011.

[32] J. Shadi Talab and M. Nadiye. "Analysis of factors affecting adoption of solar water heaters and household Rvstayy.mjlh in the areas of rural development, first period." No. 1, 2010.

[33] H. Dehghani pur. Solar water heaters. Islamic Azad University of Qazvin.2012. 
[34] Givoni. . "Climate considerations in building and urban design." NY, Van Nostrand Reinhold, pp 175-176, 1998.

[35] M. Grafiadellis and S. Kyritsis. "Heating greenhouses with solar energy." Acta Hort. Vol. 115, pp. 553-560 ILO, 1986.
[36] M. Santamouris A. Argiriou and M. Vallindras. "Design and operation of a low energy consumption passive solar agricultural greenhouse“. Solar Energy, vol. 52, no. 5, pp. 371-378, 1994. 